\title{
Renal System and Rheumatology
}

\author{
Sami Alobaidi, Manal Alotaibi, Noura Al-Zahrani, \\ and Fahmi Al-Dhaheri
}

\subsection{Introduction}

Many rheumatic diseases can be associated with different complications in kidneys and urinary tract. The goal of this chapter is to provide a summary of renal manifestations in rheumatic diseases that is easily accessible by students, residents, and practitioners.

The material presented provides a simple approach to patients presenting with renal and rheumatic manifestations. It is not meant to be an exhaustive review.

It presents a stepwise approach to the evaluation of proteinuria and hematuria in patients with rheumatic diseases. It also provides a summary on the renal complications of rheumatic diseases. The chapter also discusses lupus nephritis (LN) in more

\section{S. Alobaidi $(\bowtie)$}

Department of Medicine, College of Medicine, University of Jeddah, Jeddah, Saudi Arabia e-mail: salobaidi@uj.edu.sa

\section{Alotaibi}

Northwestern University Feinberg School of Medicine, Chicago, IL, USA

Internal Medicine Department, College of Medicine, Umm Al-Qura University, Mecca, Saudi Arabia

N. Al-Zahrani

Bahra Primary Health Care Center, Ministry of Health, Makkah, Saudi Arabia

F. Al-Dhaheri

Doctor Soliman Fakeeh Hospital,

Jeddah, Saudi Arabia detail as it is common and severe manifestation of systemic lupus erythematosus with increased risk of death and end-stage renal disease.

\subsection{Objectives}

By the end of this chapter, you should be able to:

1. Construct a diagnostic approach to patients with proteinuria or hematuria.

2. Diagnose and manage lupus nephritis (LN).

3. Discuss renal involvement in different rheumatic diseases.

4. Review the common side effects of antirheumatic medications on kidney function.

\subsection{Proteinuria}

Proteinuria screening among populations is based on measurement of albumin in random urine dipstick test. Most adolescents who have proteinuria through dipstick test do not have renal disease, and this proteinuria usually resolves on repeat testing. However, prolonged proteinuria is suggestive of kidney disease in patients with diabetes mellitus, hypertension, primary renal disease, SLE, or other systemic illnesses [1].

Proteinuria greater than $200 \mathrm{mg} / 24 \mathrm{~h}$ is considered abnormal. Urine protein excretion ranging between 200 and $3000 \mathrm{mg} / 24 \mathrm{~h}$ is termed 
sub-nephrotic range proteinuria. Nephrotic range proteinuria is typically more than $3000 \mathrm{mg} / 24 \mathrm{~h}$.

Proteinuria is an important indicator of renal disease activity and progression. It reflects an underlying pathology causing a change in the permeability properties of the glomerular filtration barrier [1]

A stepwise approach that may help physicians detect and evaluate benign and pathological causes of proteinuria is illustrated in Fig. 14.1.

\subsection{Hematuria}

Microscopic hematuria refers to the presence of erythrocytes in urine that can be exclusively detected by microscopic exam or dipstick analysis. It is a frequent reason for referral to urology or nephrology. It is often asymptomatic and found incidentally on routine urine examination.

\begin{tabular}{|c|c|}
\hline \multicolumn{2}{|c|}{ Clincal findings } \\
\hline $\begin{array}{l}\text { History of chronic diseases: Diabetes mellitus or } \\
\text { hypertension } \\
\text { History of chronic Infections: HIV, TB, hepatitis B or C } \\
\text { History of autoimmune diseases: Sjogren's, sarcoidosis, } \\
\text { SLE } \\
\text { Vasculitis: Non-specific symptoms (fatigue, myalgias, } \\
\text { muscle weakness, fever and unexplained weight loss) } \\
\text { wheezing, painful or painless oral ulcers or purulent or } \\
\text { bloody nasal discharge }\end{array}$ & $\begin{array}{l}\text { Physical Examination: Orthostatic hypotension, } \\
\text { increase in blood pressure, edema and SLE findings } \\
\text { Signs of vasculitis: Palpable purpura, paranasal sinus } \\
\text { abnormality, mononeuritis multiplex, livedo reticularis, } \\
\text { finding of diffuse high pitched wheezes on expiration, } \\
\text { ENT manifestations, evidence of hepatitis B virus } \\
\text { infection, signs of pulmonary involvement and } \\
\text { gastrointestinal involvement }\end{array}$ \\
\hline
\end{tabular}

\begin{tabular}{|l|l|}
\hline \multicolumn{2}{|c|}{ Urine Exam } \\
\hline \multicolumn{2}{|c|}{ 1- Urine dipstick test: Detects albumin only } \\
\begin{tabular}{l|l|} 
2- Microscopic analysis: To assess for urine sediments, cells \\
and other substances. Results are interpreted as follows:
\end{tabular} & $\begin{array}{l}\text { 1- 24-hour urine protein collection: The gold } \\
\text { standard test }\end{array}$ \\
$\begin{array}{l}\text { - Dysmorphic red cells: Glomerulonephritis. } \\
\text { - Red cell casts: Glomerulonephritis }\end{array}$ & $\begin{array}{l}\text { correlates well with 24-hour urine protein } \\
\text { collection }\end{array}$ \\
- WBC casts: Glomerulonephritis or interstial nephritis & \\
\hline
\end{tabular}

\begin{tabular}{|c|c|c|}
\hline \multicolumn{3}{|c|}{ Types according to the amaount of proteinuria } \\
\hline $\begin{array}{l}\text { Glomerular proteinuria: } \\
\text { It can be nephrotic or subnephrotic } \\
\text { proteinuria } \\
\text { (Nephrotic syndrome: proteinuria } \\
\text { more than } 3000 \mathrm{mg} / 24 \mathrm{hr} \text { ) } \\
\text { The more the proteinuria, the worse } \\
\text { the renal disease }\end{array}$ & $\begin{array}{l}\text { Tubular proteinuria: } \\
\text { It is caused by acute tubular } \\
\text { necrosis (ATN) } \\
\text { or other defects in kidney's tubules. } \\
\text { Proteinuria range: } 500-3500 \mathrm{mg} / 24 \mathrm{hr}\end{array}$ & $\begin{array}{l}\text { Transient proteinuria: } \\
\text { It is usually seen in a small } \\
\text { percentage of healthy individuals } \\
\text { If it persists, and is not related to } \\
\text { prolonged standing, stress, or fever, } \\
\text { then a kidney biopsy should be done }\end{array}$ \\
\hline \multicolumn{3}{|c|}{ Testing to make a diagnosis of Glomerular proteinuria } \\
\hline \multicolumn{3}{|c|}{$\begin{array}{l}\text { PR3-ANCA (c-ANCA): Granulomatosis with polyangiitis GPA (Wegener's) } \\
\text { MPO-ANCA (P-ANCA): Eosinophilic granulomatosis with polyangiitis EGPA (Churg-Strauss) } \\
\text { Anti-GBM: Goodpasture syndrome } \\
\text { Antistreptolysin O titers: Postinfectious glomerulonephritis (PSGN) } \\
\text { ANA and anti-dsDNA: SLE } \\
\text { Hepatitis serologies, RF, Cryoglobulinemia, polyarteritis nodosa (PAN) } \\
\text { Decreased C3 and C4: PSGN, SLE, cryoglobulinemia, endocarditis, and membranoproliferative glomerulonephritis } \\
\text { Lipid profile, HbA1c, HIV serology, phospholipase A2 receptor antibodies and ESR } \\
\text { Renal Biopsy }\end{array}$} \\
\hline
\end{tabular}

Fig. 14.1 Approach to a patient with proteinuria [1] 
Macroscopic (grossly visible) hematuria is more commonly associated with malignancy than microscopic hematuria. For this reason, a full investigation, including upper tract imaging and cystoscopy for the lower tract, for all patients with macroscopic hematuria is usually required.
Opinions regarding which patients with microscopic hematuria should be evaluated and need to be investigated remain controversial [2, 3].

Figures 14.2 and 14.3 provide simplified approaches to detect and evaluate significant microscopic hematuria according the recent guidelines [2, 3].

\begin{tabular}{|c|c|c|c|}
\hline \multicolumn{4}{|c|}{ Definition } \\
\hline \multicolumn{4}{|c|}{$\begin{array}{c}\text { The presence of two or more RBCs per high-power field (RBC/HPF) in } 2 \text { of } 3 \text { urine specimens } \\
\text { without recent exercise, menses, sexual activity or instrumentation. }\end{array}$} \\
\hline \multicolumn{4}{|c|}{ Causes: It can be classified according to the anatomical sources to } \\
\hline $\begin{array}{l}\text { Lower Urinary Tract } \\
\text { Urinary Tract Infection } \\
\text { (UTI) } \\
\text { Cystitis } \\
\text { Bladder stone } \\
\text { Benign bladder and } \\
\text { ureteral polyps and } \\
\text { tumors } \\
\text { Bladder cancer } \\
\text { Acute prostatitis } \\
\text { Benign prostatic } \\
\text { hyperplasia (BPH) } \\
\text { Prostate cancer } \\
\text { Urethritis } \\
\text { Urethral stricture } \\
\text { Schistosoma } \\
\text { haematobium } \\
\text { in North Africans }\end{array}$ & $\begin{array}{l}\text { Upper Urinary Tract (non- } \\
\text { glomerular) } \\
\text { Pyelonephritis } \\
\text { Nephrolithiasis } \\
\text { Hydronephrosis } \\
\text { Simple renal cyst } \\
\text { Polycystic kidney disease } \\
\text { Medullary sponge kidney } \\
\text { Hypercalciuria, hyperuricosuria, } \\
\text { or both, } \\
\text { without documented stones } \\
\text { Renal cell carcinoma } \\
\text { Papillary necrosis } \\
\text { Renal infarction } \\
\text { Renal vein thrombosis } \\
\text { Sickle cell anemia } \\
\text { Arteriovenus malformations } \\
\text { Vesicoureteral reflux }\end{array}$ & $\begin{array}{l}\text { Upper Urinary Tract } \\
\text { (glomerular) } \\
\text { IgA nephropathy } \\
\text { Thin glomerular } \\
\text { basement membrane } \\
\text { disease } \\
\text { Acute } \\
\text { glomerulonephritis } \\
\text { Lupus nephritis } \\
\text { Hereditary nephritis } \\
\text { (Alport's syndrome) } \\
\text { Mild focal } \\
\text { glomerulonephritis of } \\
\text { other causes }\end{array}$ & $\begin{array}{l}\text { Non-urinary Tract } \\
\text { Origin: } \\
\text { Menstruation } \\
\text { Trauma (sexual activity, } \\
\text { exercise, contusion) } \\
\text { "Benign hematuria" } \\
\text { (unexplained } \\
\text { microscopic } \\
\text { hematuria) } \\
\text { Over-anticoagulation } \\
\text { (usually with } \\
\text { warfarin) } \\
\text { HIV } \\
\text { Lymphoma } \\
\text { Multiple myeloma } \\
\text { Urinary tract } \\
\text { tuberculosis }\end{array}$ \\
\hline \multicolumn{4}{|c|}{ Another classification according to the frequency } \\
\hline \multicolumn{2}{|c|}{$\begin{array}{l}\text { Transient hematuria: } \\
\text { It may occur in young patients following exercise or sexual } \\
\text { intercourse } \\
\text { It can represent underlying malignancy in patients over the } \\
\text { age of } 50 \text { years } \\
\text { It can also represent UTI with the presence of other UTI signs } \\
\text { (eg, pyuria and bacteriuria) }\end{array}$} & \multicolumn{2}{|c|}{$\begin{array}{l}\text { Persistent hematuria: } \\
\text { It should always be evaluated. The more common pathologic } \\
\text { causes are kidney stones, malignancy and glomerular disease }\end{array}$} \\
\hline
\end{tabular}

\begin{tabular}{|l|}
\hline \\
History: \\
A detailed history is essential to rule out serious conditions such as urinary tract malignancy \\
Urinary tract malignancy risk factors: Age $>40$ years, tobacco use, previous radiation exposure, certain \\
occupational exposures (dyes, benzenes, aromatic amines) and medications such as cyclophosphamide \\
Transient causes: recent exercis, sexual activity and menstruation \\
The upper urinary tract causes (glomerular or non-glomerular): smoking history, fever, weight loss, flank pain, \\
trauma history, history of chronic diseases or cancers such as DM, HTN, SLE, TB, HIV, Sickle cell anemia, or Lymphoma \\
The lower urinary tract causes: Usually present with dysuria, suprapubic pain, frequency and urgency. \\
UTI: fever, dysuria and suprapubic pain
\end{tabular}

Fig. 14.2 approach to a patient with hematuria. 


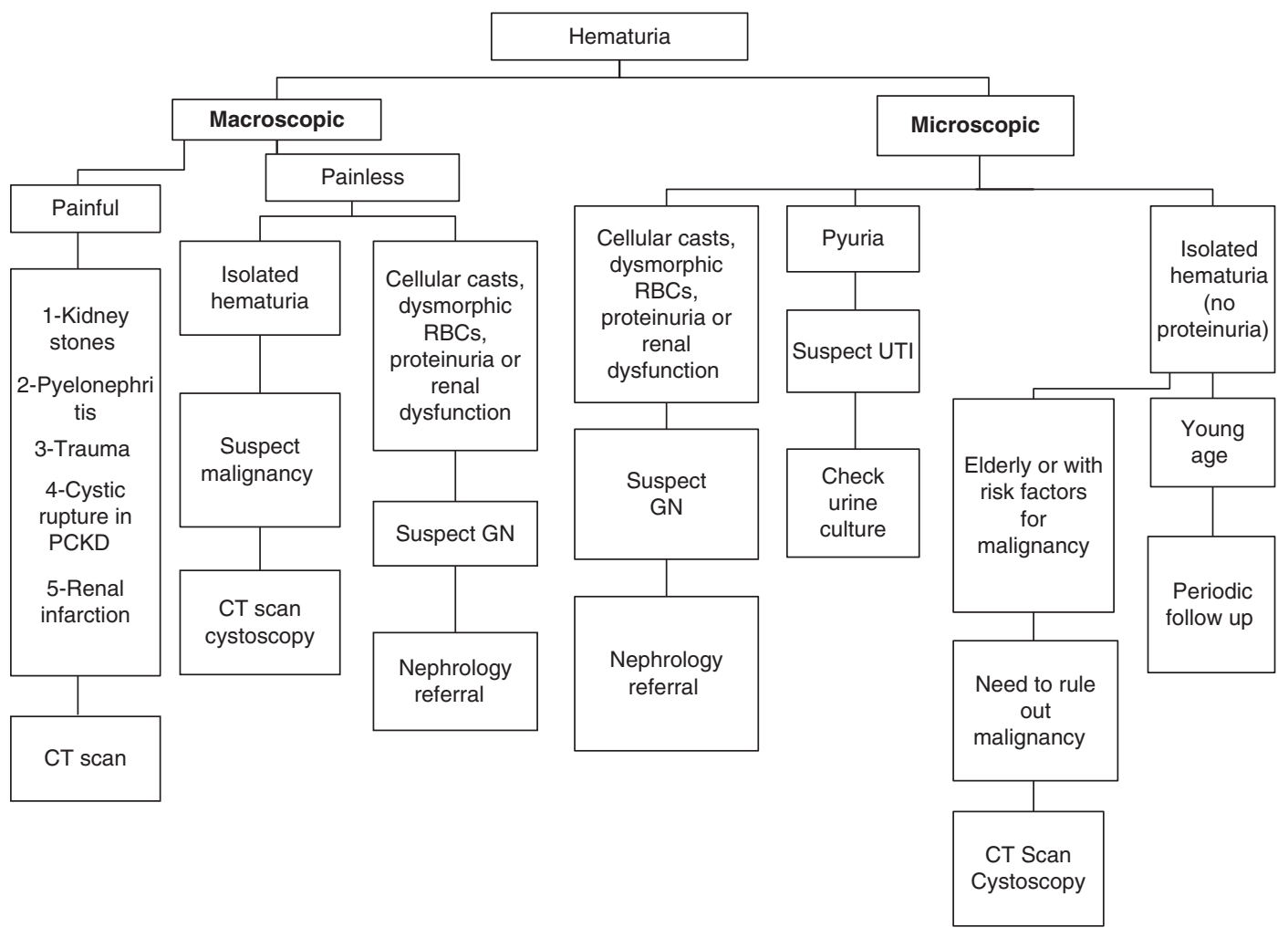

Fig. 14.3 Classification of hematuria

\subsection{Renal Involvement in Different Rheumatic Diseases}

Rheumatic diseases are frequently associated with renal complications. These complications include vascular, glomerular, and tubulointerstitial changes.

Drug-induced renal impairment should be included in the differential diagnosis of renal complications in a rheumatic patient.

Renal involvement clinically manifests in many different ways. The spectrum ranges from slight functional disorders such as slight erythrocyturia/proteinuria with normal renal function to rapidly progressive renal failure. Table 14.3 provides a summary of renal involvement in different rheumatic diseases.

\subsection{Lupus Nephritis (LN)}

Renal involvement is common in SLE. It is the leading cause of morbidity and mortality in patients with lupus, characterized by the loss of self-tolerance, production of autoantibody, and development of immune complexes that deposit in the kidney to induce nephritis. Proteinuria is one of the most commonly observed abnormalities in patients with lupus nephritis [6]. 
Figure 14.4 provides an overview of pathogenesis, clinical manifestations, and complications of lupus nephritis.

\subsubsection{Diagnostic Criteria}

Criteria for lupus nephritis in patients with SLE include any of the following conditions (Table 14.1):

\section{Persistent proteinuria.}

- $500 \mathrm{mg} / 24 \mathrm{~h}$ protein

- $3+$ protein on urine dipstick

- Spot urine protein/creatinine ratio $>0.5$ $\mathrm{mg} / \mathrm{mg}$.

2. Cellular casts.

3. Active urinary sediment ( $>5$ red blood cells/ high power field [RBC/hpf], $>5$ white blood cells[WBC]/hpf in the absence of infection, or cellular casts limited to RBC or WBC casts).

4. Renal biopsy: Immune complex-mediated glomerulonephritis compatible with lupus nephritis.

5. Opinion of rheumatologist or nephrologist [11].

\subsubsection{Treatment}

The American College of Rheumatology (ACR) recommends treatment according to the International Society of Nephrology/Renal Pathology Society (ISN/ RPS) classification of lupus nephritis. (Check sect. 3 for full presentation of the recommendation for management guidelines). Response to treatment is based on several factors including age, gender, location, and race/ethnicity (Table 14.2) [14].

\subsubsection{Adjunctive Treatments}

1. Hydroxychloroquine for all patients with SLE unless contraindicated.
2. Angiotensin-converting enzyme inhibitors or angiotensin receptor blockers if proteinuria $\geq 500 \mathrm{mg} / 24 \mathrm{~h} \mathrm{[15]}$

3. Statin therapy if LDL cholesterol $>100 \mathrm{mg} / \mathrm{dL}$ ( $2.6 \mathrm{mmol} / \mathrm{L})$.

4. Control hypertension at a target of $\leq 130 / 80 \mathrm{~mm} \mathrm{Hg}$ [11]

Note: Patients with lupus should remain on antimalarial therapy even during disease quiescence as it was shown to be associated with associated with reduced risk of renal damage, improved survival, and decreased incidence of lupus flares [16].

\subsection{Sjögren's Syndrome}

Sjögren's syndrome is a chronic inflammatory disorder characterized by lymphocytic infiltration of the lacrimal and salivary glands which result in dryness of the eyes and mouth [17]. Systemic features may include arthritis, renal, hematopoietic, pulmonary involvement, and vasculitis (Fig. 14.5). These manifestations are secondary to vasculitis, autoantibody-mediated mechanisms, or lymphocytic infiltration of the target organs. The prevalence of renal involvement ranges from 2 to $67 \%$ [22].

\subsection{Cryoglobulinemic Syndrome (CG)}

Cryoglobulinemic vasculitis is an immunecomplex-mediated disease caused by the deposition of cryoglobulins in the small- and medium-sized arteries and veins. Renal involvement is noted in around $20 \%$ of patients with mixed cryoglobulinemic vasculitis and usually diagnosed 2.5 years after the disease onset. Membranoproliferative glomerulonephritis is reported in around $80 \%$ of patients [23]. Figure 14.6 provides an overview of renal involvements in CG. 


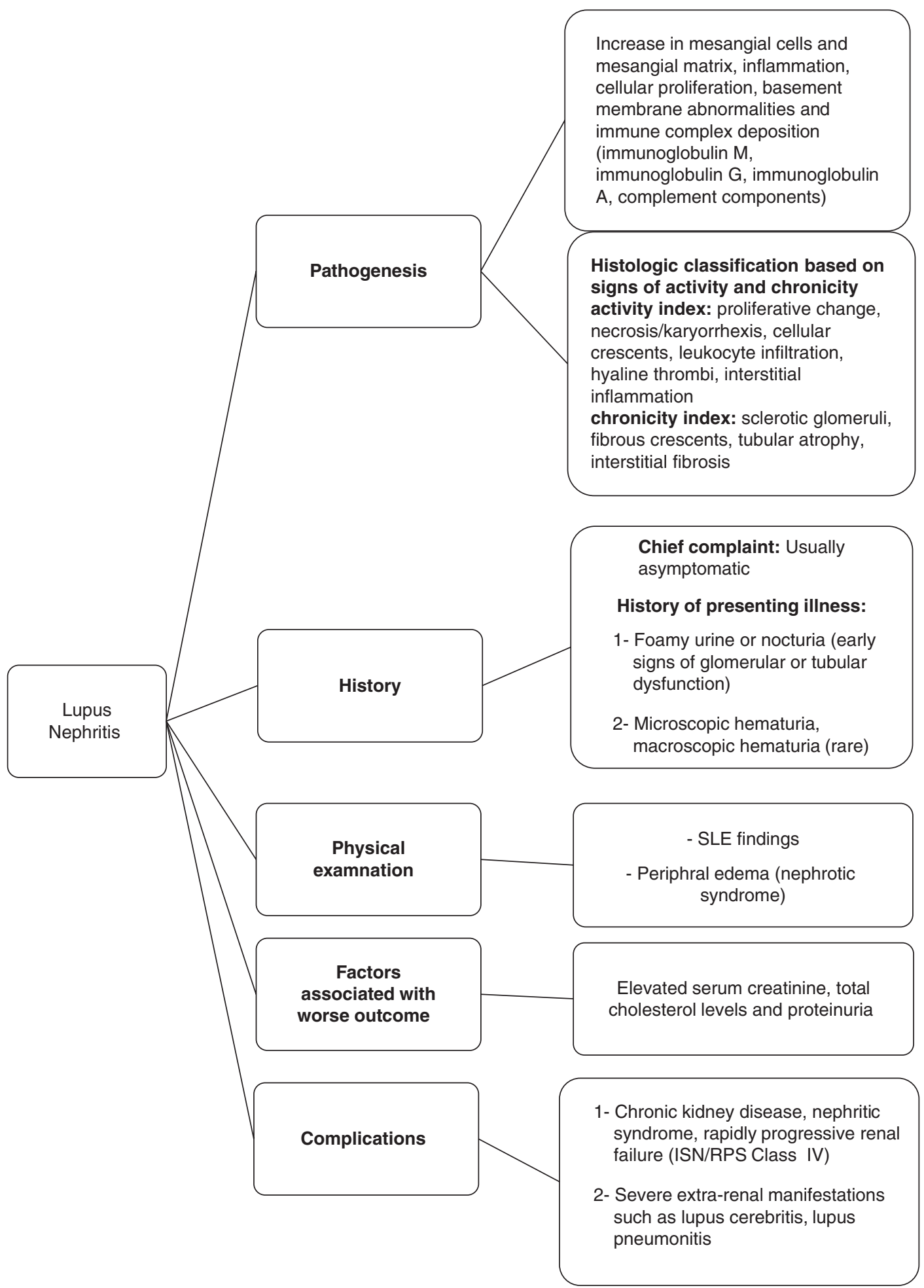

Fig. 14.4 Overview of pathogenesis, clinical manifestations, and complications of lupus nephritis [7-9] 
Table 14.1 Recommended workup for suspected lupus nephritis

\begin{tabular}{|c|c|c|}
\hline Tests & Findings & Analysis \\
\hline & Serum creatinine & To evaluate renal functions [6] \\
\hline & Antinuclear antibodies (ANA) & $\begin{array}{l}\text { Frequently positive in patient with connective tissue } \\
\text { disease and high sensitive for SLE and drug-induced lupus } \\
\text { [6] }\end{array}$ \\
\hline & $\begin{array}{l}\text { Anti-double-strand DNA } \\
\text { antibodies (anti ds-DNA) }\end{array}$ & $\begin{array}{l}\text { High in patient with } \mathrm{LN} \text {, it plays an important role in } \\
\text { induction of tissue damage, and it correlates with disease } \\
\text { activity [6] }\end{array}$ \\
\hline & $\begin{array}{l}\text { Antiphospholipid antibodies } \\
\text { (APLA) }\end{array}$ & $\begin{array}{l}\text { To evaluate autoimmune disease especially SLE, its } \\
\text { presence means increase risk of thrombosis [6] }\end{array}$ \\
\hline & Anti-C1q antibodies & $\begin{array}{l}\text { It is sensitive and specific to diagnosis of lupus nephritis } \\
\text { and evaluating the disease activity [10] }\end{array}$ \\
\hline & $\begin{array}{l}\text { Complement } 3(\mathrm{C} 3) \text { and } \\
\text { complement } 4 \text { (C4) }\end{array}$ & $\begin{array}{l}\text { Lack of C3 and C4 may indicate lupus nephritis because } \\
\text { the presences of these complement components exert a } \\
\text { protective effect against disease onset, although it may be } \\
\text { normal [6] }\end{array}$ \\
\hline \multirow[t]{5}{*}{ Urine studies } & Persistent proteinuria & $\begin{array}{l}\text { - Increases incrementally within severity classes } \\
->500 \mathrm{mg} / 24 \mathrm{~h} \text { protein } \\
->3+\text { protein on urine dipstick } \\
\text { - Spot urine protein/creatinine ratio }>0.5[6,11]\end{array}$ \\
\hline & Dysmorphic erythrocytes & - Indicate inflammatory glomerular disease $[6,11]$ \\
\hline & $\mathrm{RBC}$ or WBC cells & $\begin{array}{l}\text { - }(>5 \text { red blood cells/high power field }[\mathrm{RBC} / \mathrm{hpf}],>5 \\
\text { white blood cells }[\mathrm{WBC}] / \mathrm{hpf} \text { in the absence of infection } \\
\text { - Indicate glomerulonephritis or tubulointerstitial disease } \\
{[6,11]}\end{array}$ \\
\hline & Cellular casts & $\begin{array}{l}\text { - RBC or WBC casts which indicate inflammatory } \\
\text { glomerular disease }[6,11]\end{array}$ \\
\hline & Lipiduria & $\begin{array}{l}\text { - May result from abnormal glomerular permeability [6, } \\
\text { 11] }\end{array}$ \\
\hline \multirow[t]{2}{*}{ Renal biopsy } & Indications & $\begin{array}{l}\text { American College of Rheumatology (ACR) } \\
\text { recommendations }\end{array}$ \\
\hline & $\begin{array}{l}1 \text { to confirm suspected } \\
\text { nephritis } \\
2 \text { to evaluate disease } \\
\text { activity and damage } \\
3 \text { to determine appropriate } \\
\text { therapy } \\
4 \text { to make sure that the type, } \\
\text { duration, and intensity of } \\
\text { treatment matches the } \\
\text { severity of disease } \\
5 \text { to predict outcome and } \\
\text { identify the alternative } \\
\text { causes of renal disease }\end{array}$ & $\begin{array}{l}\text { - Biopsy is highly recommended in patients with systemic } \\
\text { lupus erythematosus with the following: } \\
\text { Increasing serum creatinine without alternative cause } \\
\text { (such as sepsis, hypovolemia, or medication induced). } \\
\text { Confirmed proteinuria } \geq 1000 \mathrm{mg} / 24 \mathrm{~h} \text { (either } 24-\mathrm{hr} \\
\text { urine specimens or spot protein/creatinine ratios). } \\
\text { Combinations of following (confirmed in } \geq 2 \text { tests } \\
\text { done within short period and in the absence of } \\
\text { alternative causes). } \\
\text { Proteinuria } \geq 500 \mathrm{mg} / 24 \mathrm{~h} \text { plus hematuria ( } \geq 5 \text { red } \\
\text { blood cells per high power field). } \\
\text { Proteinuria } \geq 500 \mathrm{mg} / 24 \mathrm{~h} \text { plus cellular casts. } \\
\text { All patients with clinical evidence of active lupus } \\
\text { nephritis, previously untreated, should have renal } \\
\text { biopsy to classify glomerular disease by current } \\
\text { International Society of Nephrology/Renal Pathology } \\
\text { Society (ISN/ RPS) classification (unless biopsy is } \\
\text { strongly contraindicated) [11] } \\
\text { Second biopsy: To detect disease progression } \\
\text { Indications: } \\
\text { 1. When the patient does not respond to therapy } \\
\text { 2. In case of worsening of renal function [12] }\end{array}$ \\
\hline
\end{tabular}


Table 14.2 Summary of the classification and treatment of lupus nephritis $[11,13]$

\begin{tabular}{l|l}
\hline Classifications of lupus nephritis & Treatment \\
\hline $\begin{array}{l}\text { Class I (minimal mesangial LN) } \\
\text { proliferative LN) }\end{array}$ & Treated as dictated by the extra-renal clinical manifestations of lupus \\
\hline $\begin{array}{l}\text { Class III LN (focal LN) and class } \\
\text { IV (diffuse LN) }\end{array}$ & $\begin{array}{l}\text { Initial therapy: Corticosteroids (1 mg/kg, to be tapered according to clinical } \\
\text { response) combined with either cyclophosphamide (500 mg IV every } 2 \text { weeks } \\
\text { for } 6 \text { doses) or mycophenolate mofetil (up to } 3 \mathrm{~g} \text { per day as tolerated) } \\
\text { Maintenance therapy: Mycophenolate mofetil (1-2 g/d in divided doses) or } \\
\text { azathioprine (1.5-2.5 mg/kg/d) and low-dose oral corticosteroids }(\leq 10 \mathrm{mg} / \mathrm{d} \\
\text { prednisone equivalent) }\end{array}$ \\
\hline Class V LN (membranous LN) & $\begin{array}{l}\text { Non-nephrotic-range proteinuria: Angiotensin-converting enzyme } \\
\text { inhibitors or angiotensin receptor blockers. Corticosteroids and } \\
\text { immunosuppressive therapy use is dictated by the presence of extrarenal } \\
\text { manifestations of lupus } \\
\text { Persistent nephrotic-range proteinuria: Corticosteroids plus an additional } \\
\text { immunosuppressive agent-(Cyclophosphamide, tacrolimus, cyclosporine), } \\
\text { mycophenolate mofetil or azathioprine }\end{array}$ \\
\hline $\begin{array}{l}\text { Class VI LN (advanced sclerosis } \\
\text { LN) }\end{array}$ & $\begin{array}{l}\text { Treated with corticosteroids and immunosuppressive therapy only as dictated } \\
\text { by the extra-renal manifestations of lupus. Discussion of renal replacement } \\
\text { therapy (dialysis vs kidney transplant) }\end{array}$ \\
\hline
\end{tabular}

\subsection{Scleroderma}

Scleroderma is manifested by widespread progressive fibrosis of the skin and internal organs due to accumulation of collagen. Renal involvement occurs in around half of the patients and is manifested as mild proteinuria, worsening kidney function, and/or hypertension (Fig. 14.7) [26]. Scleroderma renal crisis is the most serious renal manifestation which occurs in 5 to $10 \%$ of patients with systemic sclerosis, more commonly in diffuse cutaneous systemic sclerosis [27].

\subsubsection{Rheumatoid Arthritis (RA)}

Rheumatoid arthritis is a systemic inflammatory disorder of unknown etiology that primarily involves the joints. It has been reported that the annual incidence of rheumatoid arthritis is around 40 per 100,000 . Females are affected two to three times more often than males, and the peak onset is between 50 and 75 years of age [28]. An observational study has shown that the incidence of impaired kidney function is higher in patients with rheumatoid arthritis; these changes were anticipated by many factors like cardiovascular disease, dyslipidemia, elevated sedimentation rate in the first year of rheumatoid arthritis, and NSAIDs use [29]. Figure 14.8 provides an overview of renal involvement in RA.

\subsubsection{Renal Involvement in Vasculitis}

\subsubsection{Polyarteritis Nodosa (PAN)}

It is a systemic necrotizing vasculitis of mediumsized and occasionally small vessels [34]. It is a rare disease and characterized by the absence of antineutrophil cytoplasmic antibodies (ANCA) [34]. Any organ can be affected including the kidneys (renal artery involvement is common and leads to stenosis, hypertension, and eventually chronic kidney disease) (Fig. 14.9). This disease spares the lungs [34]. Most cases are idiopathic; however, $33 \%$ of cases are associated with chronic HBV infection [34]. Renal disease is the most common cause of death. It is fatal if left untreated, but has favorable response to treatment [34]. 


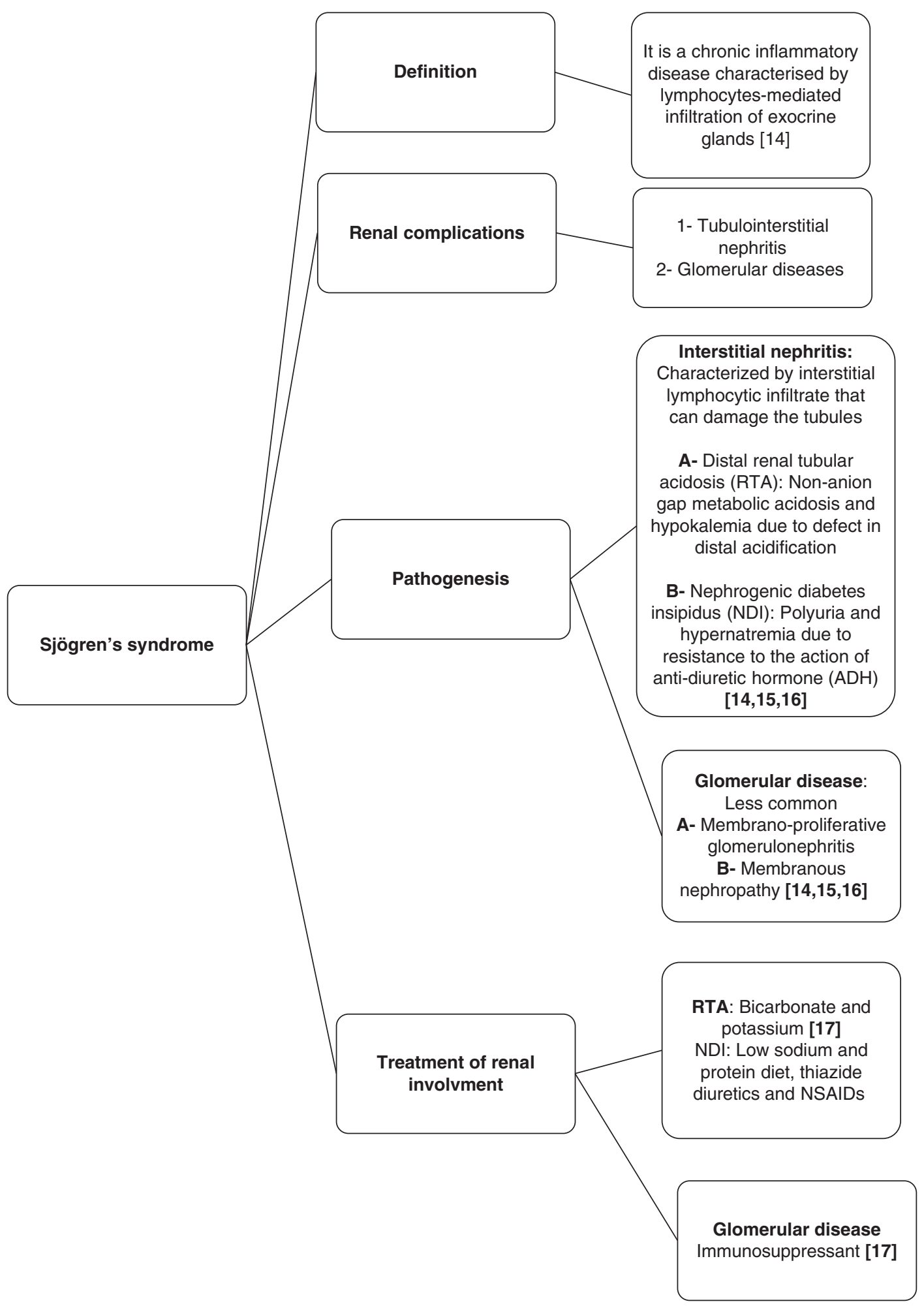

Fig. 14.5 Renal involvement in Sjögren's syndrome: [18-21] 


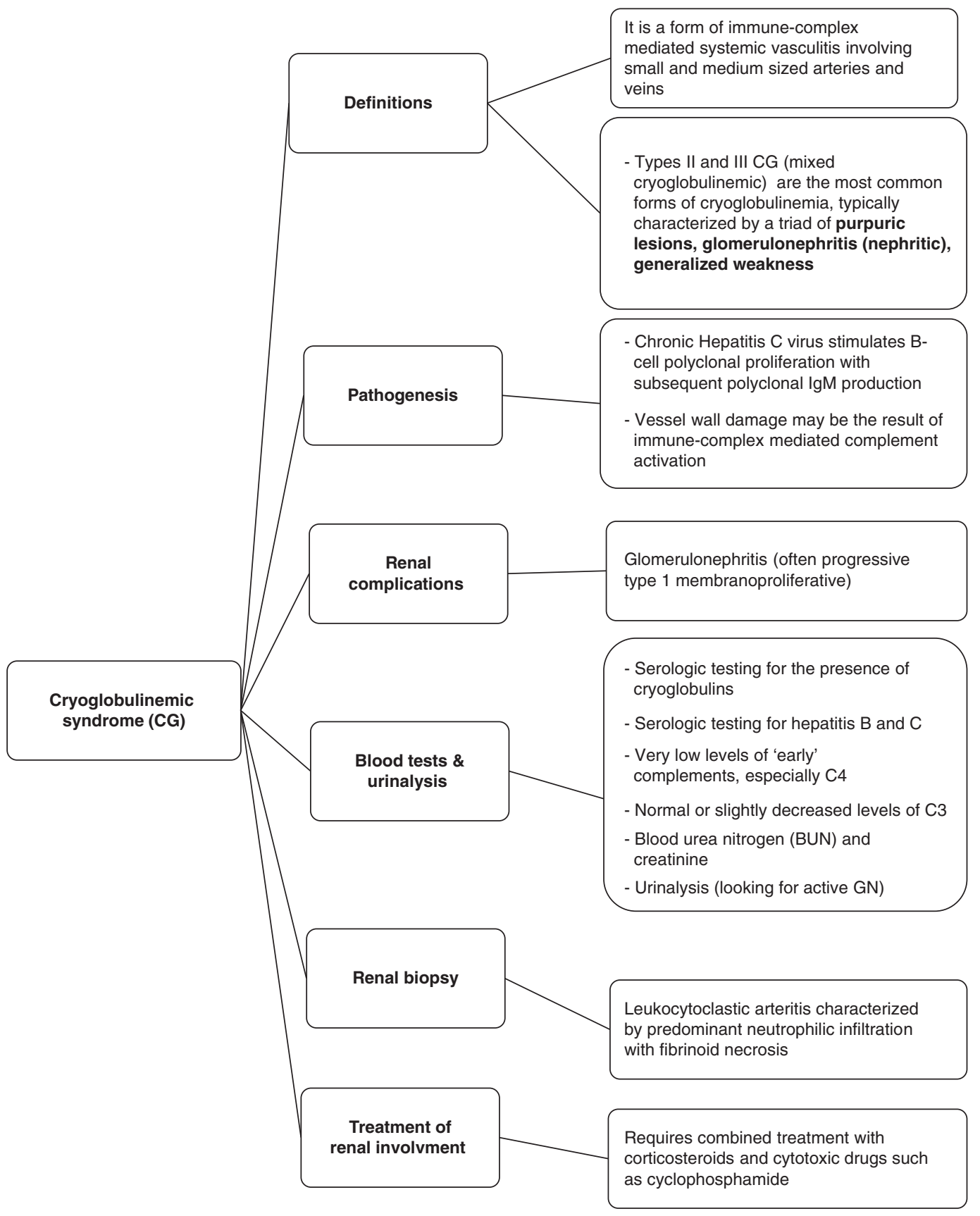

Fig. 14.6 Overview of renal involvements in CG [23] 


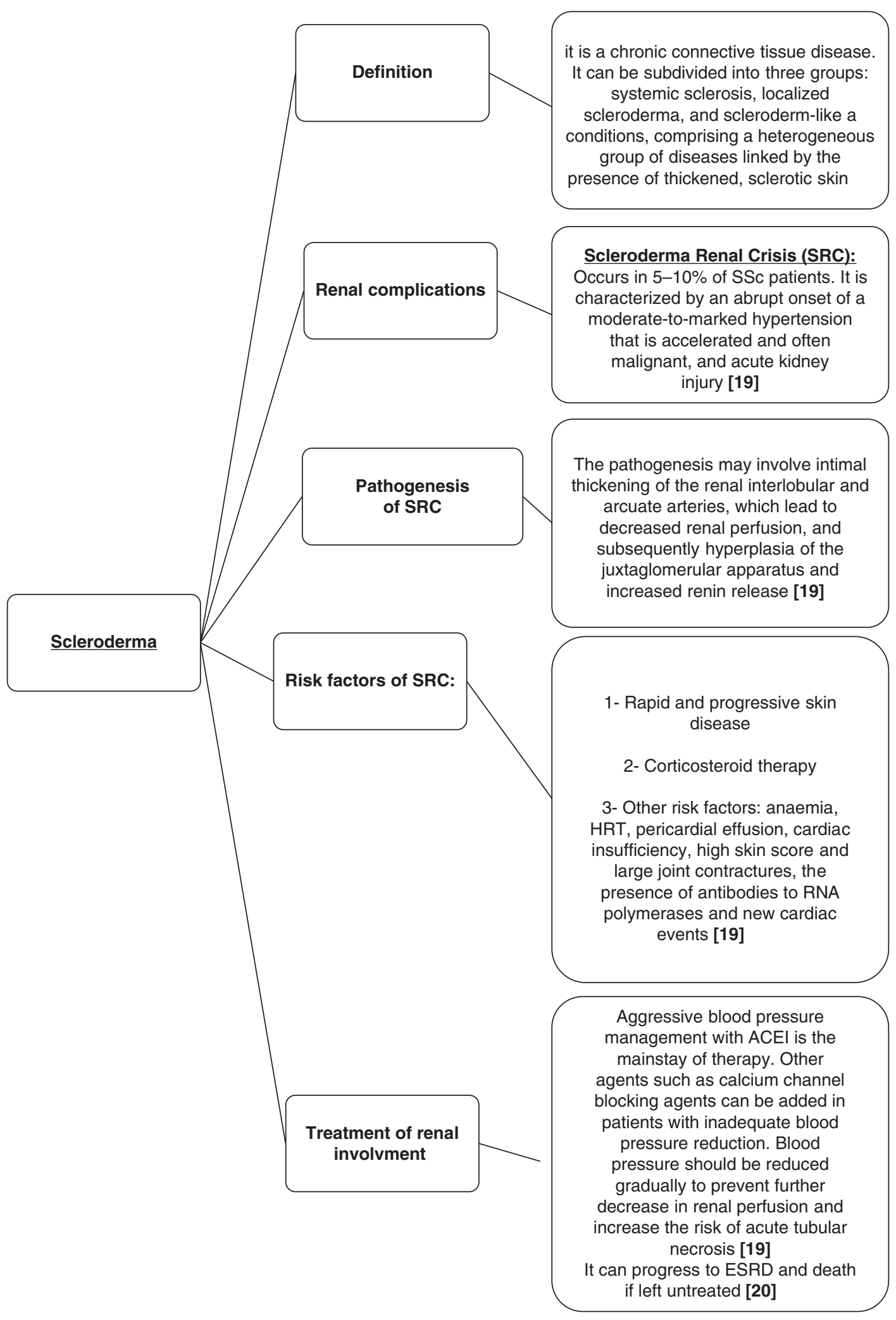

Fig. 14.7 Renal involvement in scleroderma [24, 25] 


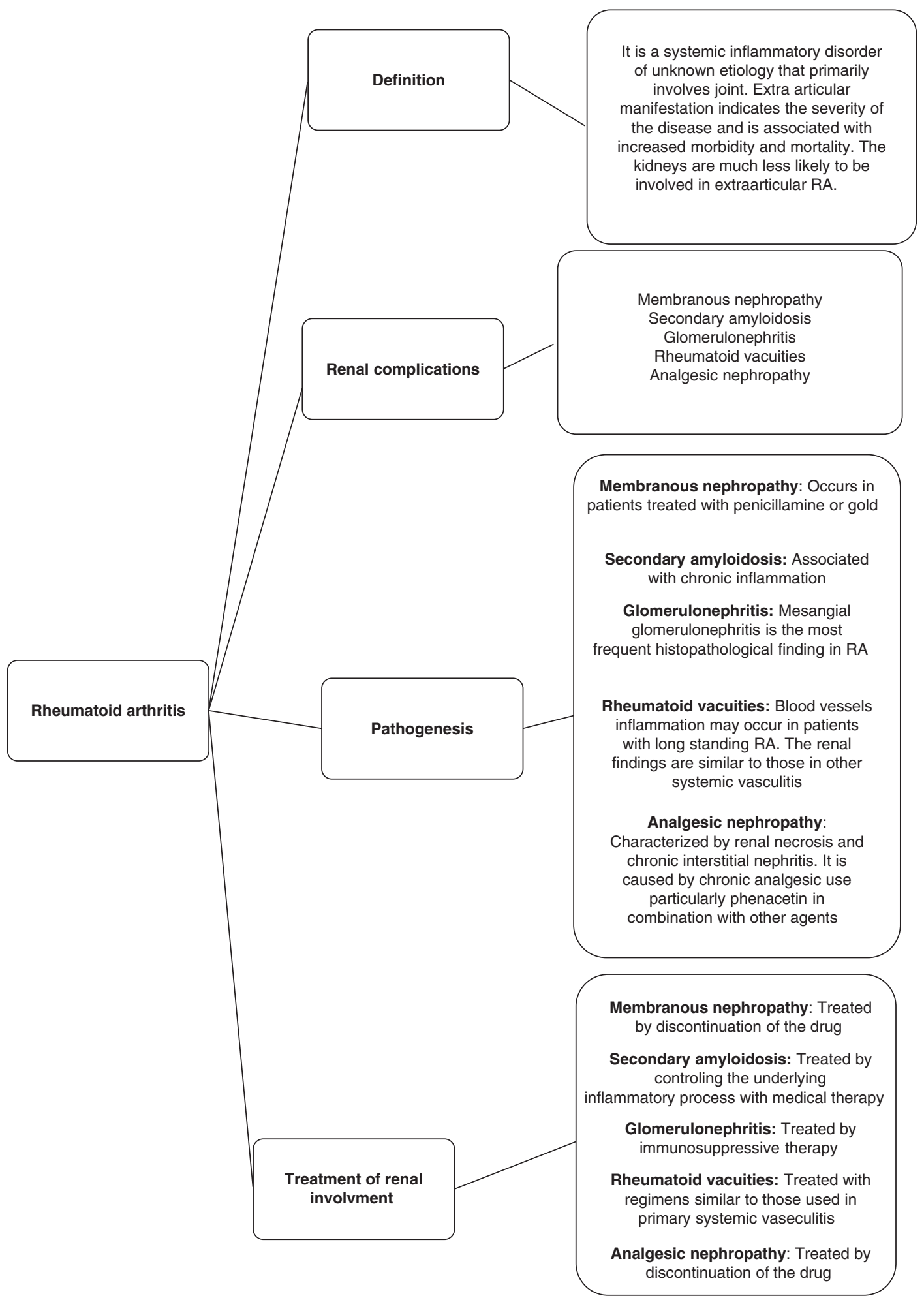

Fig. 14.8 Overview of renal involvement in RA [30-33] 


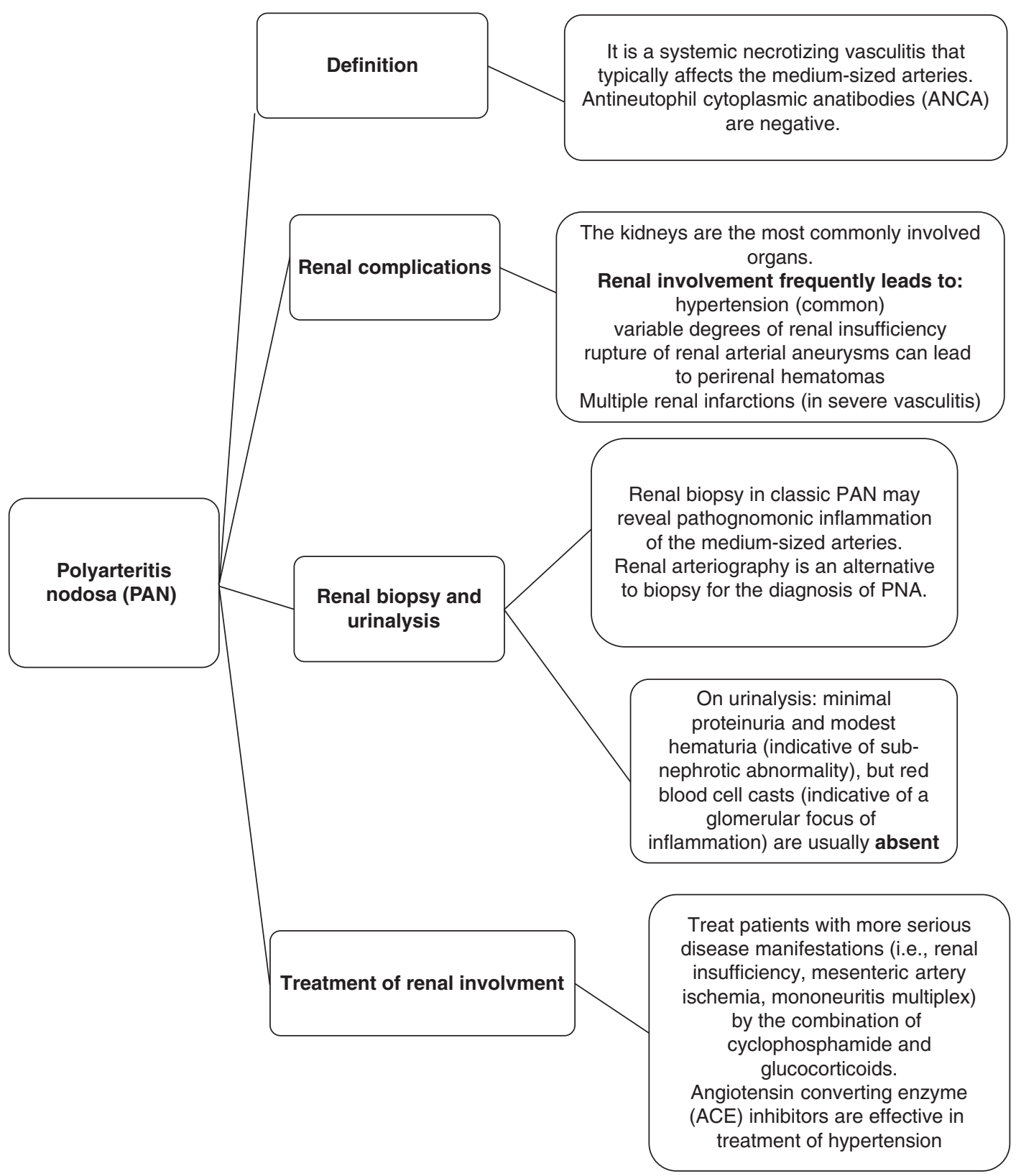

Fig. 14.9 Medium vessel vasculitis: polyarteritis nodosa (PAN) [34]

\subsubsection{Eosinophilic Granulomatosis with Polyangiitis EGPA (Churg-Strauss)}

It is a systemic necrotizing vasculitis that affects small-sized muscular arteries [35]. It is a rare disease and characterized by the presence of antineutrophil cytoplasmic antibodies (ANCA) [35]. Asthma, peripheral eosinophilia, and granulomas on histology are common associations with this disease [35]. Renal involvement can lead to pauci-immune rapidly progressive glomerulonephritis (Fig. 14.10) [35]. 


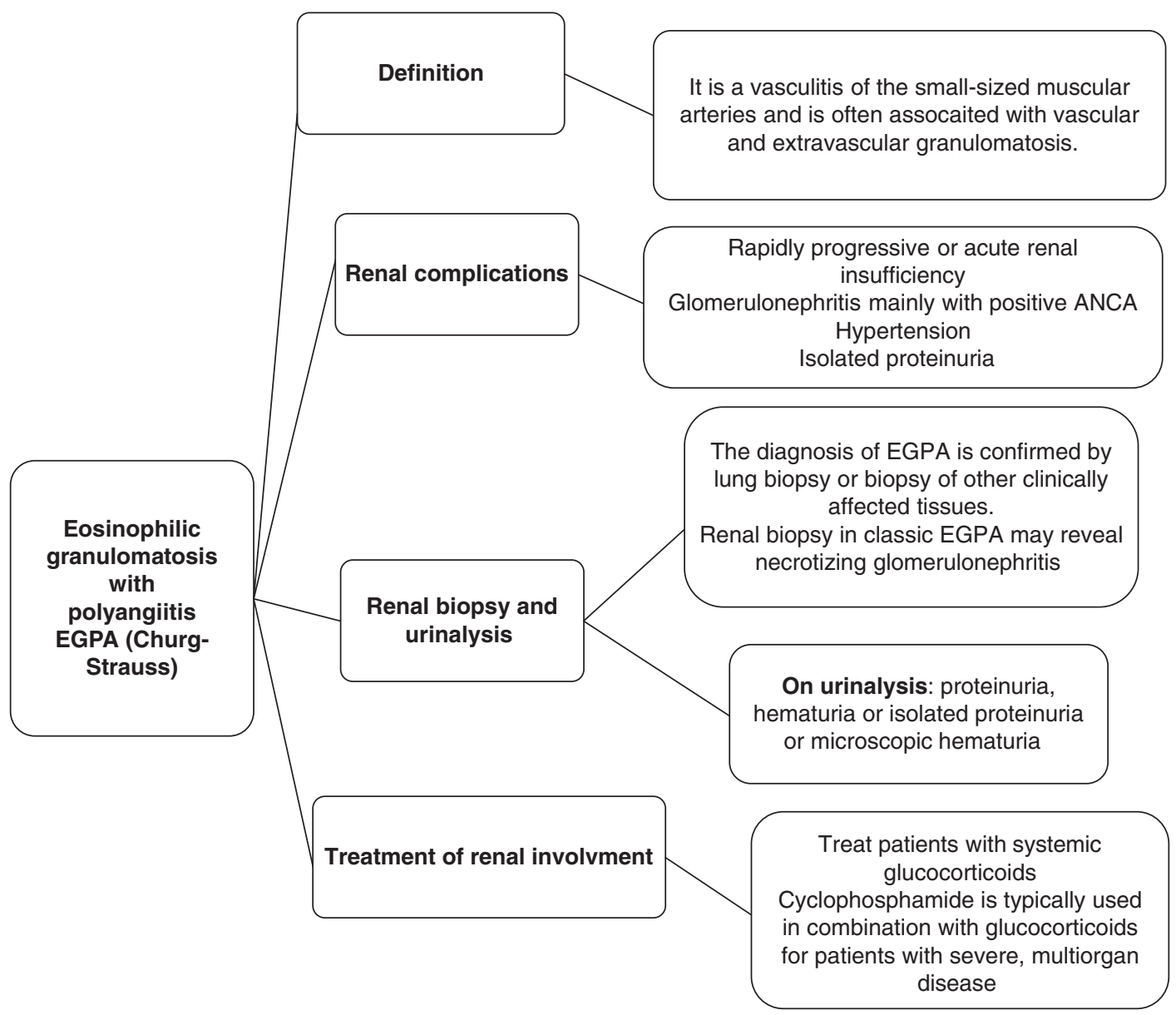

Fig. 14.10 Eosinophilic granulomatosis with polyangiitis EGPA (Churg-Strauss) [35]

\subsubsection{Granulomatosis with Polyangiitis GPA (Wegener's) and Microscopic Polyangiitis (MPA)}

These are systemic vasculitides of the medium- and small-sized arteries, as well as the venules and arterioles [29]. They are known to cause many renal complications, e.g., glomerulonephritis, acute kidney injury, and proteinuria (Fig. 14.11) [29, 30].

Rapidly progressive glomerulonephritis is a common and severe feature with Wegener's granulomatosis or proteinase-3 (PR3)-ANCA vasculitis, and it might lead to end-stage renal diseases $[29,30]$. In addition, necrotizing granulomatous inflammation is the histopathologic hallmark of GPA [29, 30]. Microscopic polyangiitis or myeloperoxidase (MPO)-ANCA vasculitis are associated with chronic renal injury more than glomerulonephritis [29, 30].

\subsubsection{Henoch-Schönlein Purpura (HSP) (IgA Vasculitis)}

It is a systemic vasculitis of the small-sized blood vessels (the post-capillary venules), characterized by the deposition of $\operatorname{IgA}$-containing immune complexes [40].

$\operatorname{Ig} \mathrm{A}$ vasculitis is considered the most common systemic vasculitis in children [40]. Renal involvement occurs in $20 \%$ to $100 \%$ of patients. HSP nephritis is common and generally mild in children (particularly young children) (Fig. 14.12). It is mainly presented with microscopic hematuria or proteinuria [40] (Table 14.3). 


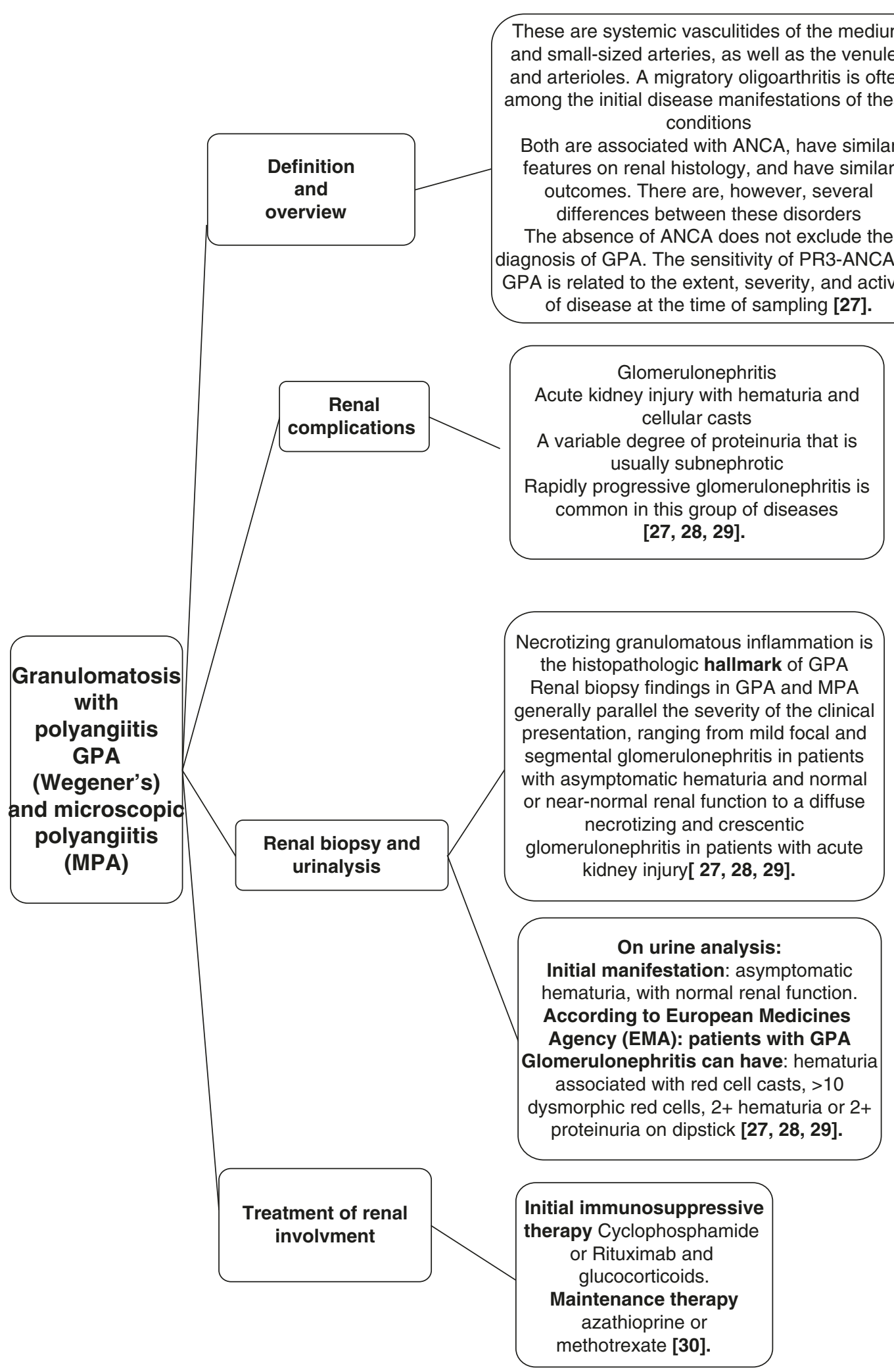

Fig. 14.11 Granulomatosis with polyangiitis GPA (Wegener's) and Microscopic Polyangiitis (MPA) [36-39] 


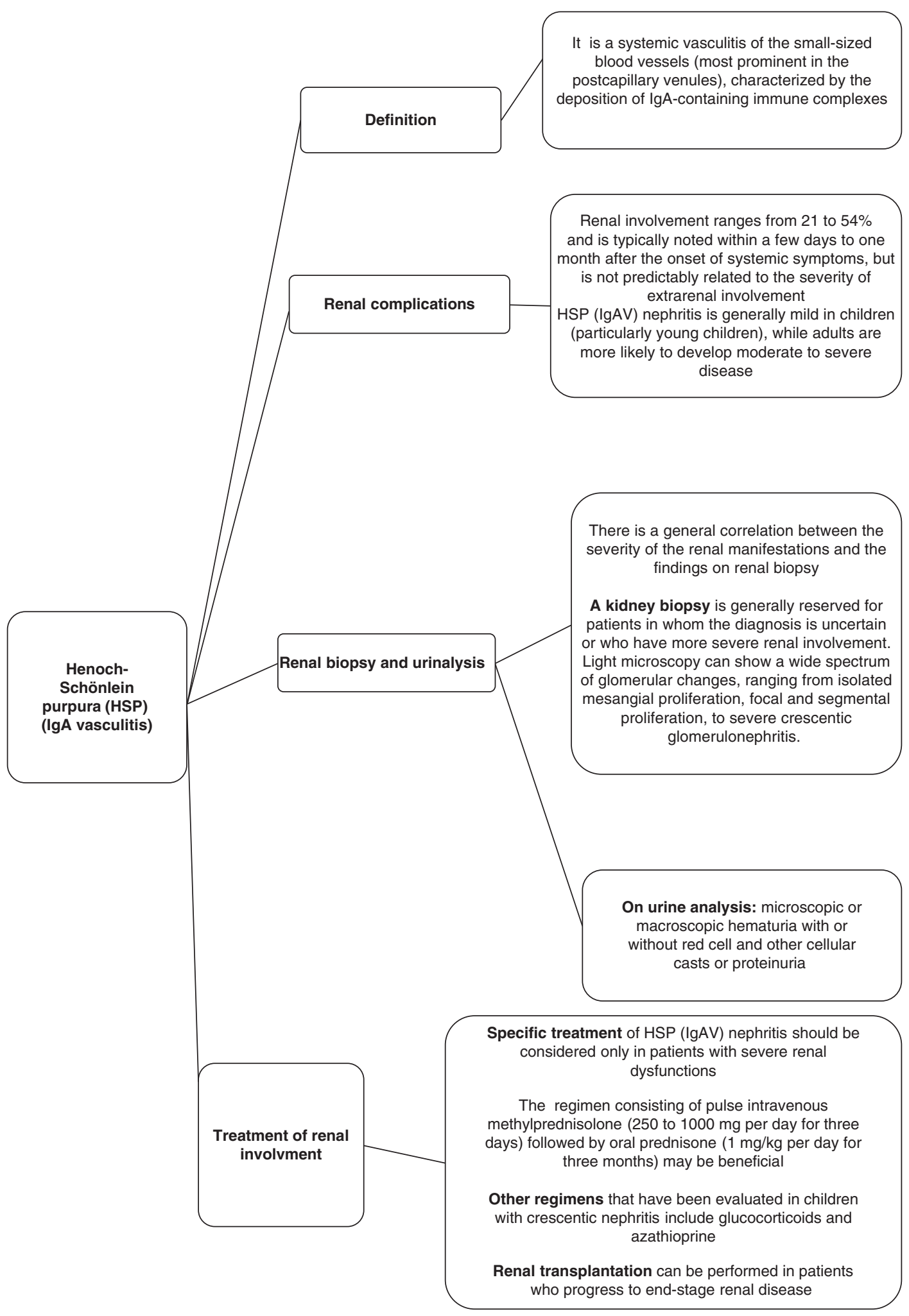

Fig. 14.12 Henoch-Schönlein purpura (HSP) (IgA vasculitis) [40] 
Table 14.3 Summary of renal involvement in different rheumatic diseases

\begin{tabular}{|c|c|}
\hline Rheumatic disease & Renal complications \\
\hline $\begin{array}{l}\text { Systemic lupus } \\
\text { erythematosus }\end{array}$ & $\begin{array}{l}\text { - Interstitial nephritis. } \\
\text { - Necrotizing vasculitis. } \\
\text { - Glomerulosclerosis. } \\
\text { - Chronic kidney disease. } \\
\text { - Nephritic syndrome. } \\
\text { - Rapidly progressive renal failure. }\end{array}$ \\
\hline Sjögren's syndrome & $\begin{array}{l}\text { - Interstitial nephritis (may precede onset of sicca symptoms). } \\
\text { - Renal tubular acidosis (types I and II) (in 11\%). } \\
\text { - Interstitial cystitis (rare). } \\
\text { - Glomerulonephritis (rare). } \\
\text { - Nephrolithiasis (rare). }\end{array}$ \\
\hline Cryoglobulinemia & • Membranoproliferative glomerulonephritis (60 to 80\%). \\
\hline $\begin{array}{l}\text { Henoch-Schönlein } \\
\text { purpura (HSP) (IgA } \\
\text { vasculitis) }\end{array}$ & $\begin{array}{l}\text { - Hematuria with or without proteinuria. } \\
\text { - Isolated hematuria. } \\
\text { - Nephritic syndrome. } \\
\text { - Renal insufficiency. } \\
\text { - Hypertension. } \\
\text { - End-stage renal failure. }\end{array}$ \\
\hline $\begin{array}{l}\text { Polyarteritis } \\
\text { Nodosa }\end{array}$ & $\begin{array}{l}\text { - Hypertension (common). } \\
\text { - Variable degrees of renal insufficiency. } \\
\text { - Rupture of renal arterial aneurysms can lead to perirenal hematomas. } \\
\text { - Multiple renal infarctions (in severe vasculitis). }\end{array}$ \\
\hline $\begin{array}{l}\text { Granulomatosis with } \\
\text { polyangiitis GPA } \\
\text { (Wegener's) and } \\
\text { microscopic polyangiitis } \\
\text { (MPA) }\end{array}$ & $\begin{array}{l}\text { - Glomerulonephritis. } \\
\text { - Acute kidney injury with hematuria and cellular casts. } \\
\text { - Subnephrotic proteinuria. } \\
\text { - Rapidly progressive glomerulonephritis. }\end{array}$ \\
\hline $\begin{array}{l}\text { Eosinophilic } \\
\text { granulomatosis with } \\
\text { polyangiitis EGPA } \\
\text { (Churg-Strauss) }\end{array}$ & $\begin{array}{l}\text { - Focal segmental glomerulonephritis common but renal failure rare. } \\
\text { - Rapidly progressive or acute renal insufficiency. } \\
\text { - Glomerulonephritis mainly with positive ANCA. } \\
\text { - Hypertension. } \\
\text { - Isolated proteinuria. }\end{array}$ \\
\hline $\begin{array}{l}\text { Rheumatoid arthritis } \\
\text { (RA) }\end{array}$ & $\begin{array}{l}\text { - Acute tubular necrosis related to nonsteroidal anti-inflammatory drug (NSAID) } \\
\text { use. } \\
\text { - Secondary amyloidosis due to the chronic inflammation; it is now relatively rare in } \\
\text { RA. } \\
\text { - Nephrotic syndrome secondary to membranous nephropathy. } \\
\text { - Necrotizing glomerulonephritis. } \\
\text { - Destructive inflammation within the walls of renal arteries. }\end{array}$ \\
\hline $\begin{array}{l}\text { Mixed connective tissue } \\
\text { disease (MCTD) }\end{array}$ & $\begin{array}{l}\text { - Glomerulonephritis. } \\
\text { - Renal vasculopathy. } \\
\text { - Malignant hypertension. } \\
\text { - Immune complex-mediated nephritis. } \\
\text { - Interstitial nephropathy. } \\
\text { - Severe renal disease (rare) [4] }\end{array}$ \\
\hline Scleroderma & $\begin{array}{l}\text { - Renal impairment usually mild. } \\
\text { - Scleroderma renal crisis rare (occurs in 1\%-10\%). }\end{array}$ \\
\hline Ankylosing spondylitis & $\begin{array}{l}\text { - Secondary renal amyloidosis. } \\
\text { - Immunoglobulin A (IgA) nephropathy. } \\
\text { - Membranoproliferative glomerulonephritis. } \\
\text { - Treatment-associated nephrotoxicity. } \\
\text { - Membranous glomerulonephritis (rare). } \\
\text { - Focal glomerulosclerosis (rare). } \\
\text { - Proliferative glomerulonephritis (rare) [5] }\end{array}$ \\
\hline
\end{tabular}


Table 14.4 Renal side effects of commonly used drugs in rheumatic diseases

\begin{tabular}{|c|c|}
\hline Drugs & Renal side effect \\
\hline NSAIDs & $\begin{array}{l}\text { - Acute tubular necrosis (ATN) } \\
\text { - Acute interstitial nephritis (AIN) } \\
\text { - Analgesic nephropathy: papillary necrosis and chronic interstitial } \\
\text { nephritis } \\
\text { - Minimal change disease } \\
\text { - Membranous glomerulonephritis } \\
\text { - Hyperkalemia } \\
\text { - Hyponatremia } \\
\text { - Salt and water retention } \\
\text { - Renal tubular acidosis }\end{array}$ \\
\hline $\begin{array}{l}\text { Cyclooxygenase- } 2(\mathrm{COX}-2) \\
\text { selective inhibitors }\end{array}$ & $\begin{array}{l}\text { Acute kidney injury } \\
\text { Salt and water retention }\end{array}$ \\
\hline $\begin{array}{l}\text { Calcineurin inhibitors (cyclosporine } \\
\text { and tacrolimus) }\end{array}$ & $\begin{array}{l}\text { Acute kidney injury } \\
\text { Hyperkalemia } \\
\text { Chronic interstitial fibrosis and tubular atrophy } \\
\text { Hypophosphatemia } \\
\text { Hypomagnesaemia } \\
\text { Global glomerular sclerosis } \\
\text { Focal segmental glomerulosclerosis }\end{array}$ \\
\hline Methotrexate & Crystal-induced AKI (mainly with high dose IV) \\
\hline Sulfasalazine & $\begin{array}{l}\text { Interstitial nephritis (rare) } \\
\text { Nephrotic syndrome (rare) }\end{array}$ \\
\hline Leflunomide & Interstitial nephritis (rare) \\
\hline Gold & Membranous glomerulonephritis \\
\hline Bisphosphonates & $\begin{array}{l}\text { Acute tubular necrosis } \\
\text { Focal segmental glomerulosclerosis } \\
\text { Minimal change disease }\end{array}$ \\
\hline Penicillamine & $\begin{array}{l}\text { Membranous glomerulonephritis } \\
\text { Minimal change disease }\end{array}$ \\
\hline Azathioprine & Interstitial nephritis (rare) \\
\hline
\end{tabular}

\subsubsection{Renal Side Effects of DMARDs and NSAIDs}

Renal toxicity of disease-modifying antirheumatic drugs (DMARDs) and nonsteroidal antiinflammatory drugs (NSAIDs) varies depending on the age and the kidney function of the patient. Side effects are commonly observed in elderly patients with compromised kidney function. Therefore, the use of NSAID should be avoided in patients with chronic kidney disease. Cyclosporine, gold, and penicillamine are associated with more serious renal side effects. Fortunately, gold and penicillamine are now very rarely used for the treatment of rheumatic diseases. Others like methotrexate, azathioprine, antimalarials, sulfasalazine, and leflunomide are safer with relatively less renal toxicity $[35,36]$.
Table14.4 summarized the renal side effects of commonly used drugs in rheumatic diseases.

Acknowledgments The authors would like to thank Dr. Waleed Hafiz for his assistance in the development of this chapter.

\section{References}

1. Ellam TJ, El Nahas M. Proteinuria thresholds are irrational: a call for proteinuria indexing. Nephron Clin Pract. 2011;118(3):c217-24.

2. Wollin T, Laroche B, Psooy K. Canadian guidelines for the management of asymptomatic microscopic hematuria in adults. Can Urol Assoc J. 2009;3(1):77-80.

3. Grossfeld GD, et al. Evaluation of asymptomatic microscopic hematuria in adults: the American urological association best practice policy--part I: definition, detection, prevalence, and etiology. Urology. 2001;57(4):599-603. 
4. Ortega-Hernandez OD, Shoenfeld Y. Mixed connective tissue disease: an overview of clinical manifestations, diagnosis and treatment. Best Pract Res Clin Rheumatol. 2012;26(1):61-72.

5. McVeigh CM, Cairns AP. Diagnosis and management of ankylosing spondylitis. BMJ. 2006;333(7568):581-5.

6. Tang S, Lui SL, Lai KN. Pathogenesis of lupus nephritis: an update. Nephrology (Carlton). 2005;10(2):174-9.

7. Austin, H.A., 3rd, et al., Predicting renal outcomes in severe lupus nephritis: contributions of clinical and histologic data. Kidney Int, 1994. 45(2): p. 544-550.

8. Tisseverasinghe A, et al. Association between serum total cholesterol level and renal outcome in systemic lupus erythematosus. Arthritis Rheum. 2006;54(7):2211-9.

9. Balow JE. Clinical presentation and monitoring of lupus nephritis. Lupus. 2005;14(1):25-30.

10. Loizou S, et al. Significance of anticardiolipin and anti-beta(2)-glycoprotein I antibodies in lupus nephritis. Rheumatology (Oxford). 2000;39(9):962-8.

11. Hahn BH, et al. American College of Rheumatology guidelines for screening, treatment, and management of lupus nephritis. Arthritis Care Res (Hoboken). 2012;64(6):797-808.

12. Mittal B, Rennke H, Singh AK. The role of kidney biopsy in the management of lupus nephritis. Curr Opin Nephrol Hypertens. 2005;14(1):1-8.

13. KDIGO Clinical Practice Guideline for Glomerulonephritis. http://www.kidney-international. org, 2012. 2(2): p. 143.

14. Liu LL, et al. Efficacy and safety of mycophenolate mofetil versus cyclophosphamide for induction therapy of lupus nephritis: a meta-analysis of randomized controlled trials. Drugs. 2012;72(11):1521-33.

15. Duran-Barragan S, et al. Angiotensin-converting enzyme inhibitors delay the occurrence of renal involvement and are associated with a decreased risk of disease activity in patients with systemic lupus erythematosus--results from LUMINA (LIX): a multiethnic US cohort. Rheumatology (Oxford). 2008;47(7):1093-6.

16. Pons-Estel GJ, et al. Protective effect of hydroxychloroquine on renal damage in patients with lupus nephritis: LXV, data from a multiethnic US cohort. Arthritis Rheum. 2009;61(6):830-9.

17. Ramos-Casals M, Tzioufas AG, Font J. Primary Sjögren's syndrome: new clinical and therapeutic concepts. Ann Rheum Dis. 2005;64(3):347-54.

18. Aasarod K, et al. Renal involvement in primary Sjogren's syndrome. QJM. 2000;93(5):297-304.

19. Bossini N, et al. Clinical and morphological features of kidney involvement in primary Sjogren's syndrome. Nephrol Dial Transplant. 2001;16(12):2328-36.

20. Maripuri S, et al. Renal involvement in primary Sjogren's syndrome: a clinicopathologic study. Clin J Am Soc Nephrol. 2009;4(9):1423-31.
21. Ramos-Casals M, et al. Topical and systemic medications for the treatment of primary Sjogren's syndrome. Nat Rev Rheumatol. 2012;8(7):399-411.

22. Pertovaara M, Korpela M, Pasternack A. Factors predictive of renal involvement in patients with primary Sjogren's syndrome. Clin Nephrol. 2001;56(1): $10-8$.

23. Dammacco F, et al. The cryoglobulins: an overview. Eur J Clin Investig. 2001;31(7):628-38.

24. Denton CP, et al. Renal complications and scleroderma renal crisis. Rheumatology (Oxford). 2009;48(Suppl 3):iii32-5.

25. Traub YM, et al. Hypertension and renal failure (scleroderma renal crisis) in progressive systemic sclerosis. Review of a 25-year experience with 68 cases. Medicine (Baltimore). 1983;62(6):335-52.

26. Steen VD, et al. Kidney disease other than renal crisis in patients with diffuse scleroderma. J Rheumatol. 2005;32(4):649-55.

27. Denton C, et al. Renal complications and scleroderma renal crisis. Rheumatology. 2009;48(suppl_3):iii32-5.

28. Sullivan PW, et al. Influence of rheumatoid arthritis on employment, function, and productivity in a nationally representative sample in the United States. J Rheumatol. 2010;37(3):544-9.

29. Hickson LJ, et al. Development of reduced kidney function in rheumatoid arthritis. Am J Kidney Dis. 2014;63(2):206-13.

30. Turesson C, et al. Occurrence of extraarticular disease manifestations is associated with excess mortality in a community based cohort of patients with rheumatoid arthritis. J Rheumatol. 2002;29(1):62-7.

31. Turesson C, et al. Rheumatoid factor and antibodies to cyclic citrullinated peptides are associated with severe extra-articular manifestations in rheumatoid arthritis. Ann Rheum Dis. 2007;66(1):59-64.

32. Gertz MA, Kyle RA. Secondary systemic amyloidosis: response and survival in 64 patients. Medicine (Baltimore). 1991;70(4):246-56.

33. Kronbichler A, Mayer G. Renal involvement in autoimmune connective tissue diseases. BMC Med. 2013;11:95.

34. Agard C, et al. Microscopic polyangiitis and polyarteritis nodosa: how and when do they start? Arthritis Rheum. 2003;49(5):709-15.

35. Sinico RA, et al. Renal involvement in ChurgStrauss syndrome. Am J Kidney Dis. 2006;47(5): 770-9.

36. de Lind van Wijngaarden RA, et al. Clinical and histologic determinants of renal outcome in ANCAassociated vasculitis: A prospective analysis of 100 patients with severe renal involvement. J Am Soc Nephrol. 2006;17(8):2264-74.

37. Hauer HA, et al. Determinants of outcome in ANCAassociated glomerulonephritis: a prospective clinicohistopathological analysis of 96 patients. Kidney Int. 2002;62(5):1732-42. 
38. Berden AE, et al. Histopathologic classification of ANCA-associated glomerulonephritis. J Am Soc Nephrol. 2010;21(10):1628-36.

39. Pagnoux C, et al. Azathioprine or methotrexate maintenance for ANCA-associated vasculitis. N Engl J Med. 2008;359(26):2790-803.
40. Halling SF, Soderberg MP, Berg UB. Henoch Schonlein nephritis: clinical findings related to renal function and morphology. Pediatr Nephrol. 2005;20(1):46-51.

Open Access This chapter is licensed under the terms of the Creative Commons Attribution 4.0 International License (http://creativecommons.org/licenses/by/4.0/), which permits use, sharing, adaptation, distribution and reproduction in any medium or format, as long as you give appropriate credit to the original author(s) and the source, provide a link to the Creative Commons license and indicate if changes were made.

The images or other third party material in this chapter are included in the chapter's Creative Commons license, unless indicated otherwise in a credit line to the material. If material is not included in the chapter's Creative Commons license and your intended use is not permitted by statutory regulation or exceeds the permitted use, you will need to obtain permission directly from the copyright holder. 